\title{
A Surviving Herd of Endangered Wood Bison at Hook Lake, N.W.T.? JACK VAN CAMP ${ }^{1}$
}

\author{
(Received 31 October 1988; accepted in revised form 6 March 1989)
}

\begin{abstract}
Bison in the Hook Lake area of the Northwest Territories (N.W.T.) are classified and managed as low value, diseased, plains bison (Bison bison bison) $\times$ wood bison (B. b. athabascae) hybrids. Their classification is founded on the hypothesis of universal hybridization in Wood Buffalo National Park (WBNP) and surrounding areas. This hypothesis is not supported by the confirmed samples of relatively pure wood bison taken from the range of the northern population of WBNP in 1963 and 1965. A proposed limited gene flow hypothesis predicts that: 1) introduced plains bison did not swamp all of the wood bison gene pools; 2) movement and genetic exchange between demes is limited; and 3) demes of relatively pure wood bison remain intact long after the hybridization episode. The probability of finding wood bison is greatest in the most remote and inaccessible Hook Lake area of the Slave River lowlands, where a small population survives after a prolonged population collapse. These animals may be at least partially descended from a relict population that predates WBNP. Historical, behavioural, morphometric, photographic and observational evidence is consistent with this hypothesis, but conclusive evidence from available taxonomic tests has not been collected.

The current set of policy, legislation and international law empowers government to protect and manage the "endangered" wood bison but provides no protection for hybrids. Because of its current bio-political status, the Hook Lake herd is in imminent danger of extirpation from overharvesting, disease and overpredation or from deliberate depopulation to eradicate disease. If the Hook Lake bison are wood bison, the implications of a status change include: 1) the empowering of government to protect and manage the remaining herd; 2) the option to salvage and restore genetic diversity to the world population of wood bison; 3 ) alternatives that would greatly simplify future management strategies for free-roaming northern bison populations; and 4) a contribution to the international objective of removing the wood bison from danger of extinction.
\end{abstract}

Key words: wildlife, bison, taxonomy, conservation

RÉSUMÉ. Les bisons de la région de Hook Lake dans les Territoires du Nord-Ouest (T. du N.-O.) sont classifiés et considérés comme des hybrides provenant du croisement du bison des plaines (Bison bison bison) et du bison des bois (B. b. athabascae). On s'est fondé pour cette classification sur l'hypothèse de l'hybridation universelle dans le parc national de Wood Buffalo et les zones environnantes. Cette hypothèse n'est pas appuyée par les échantillons homologués de bisons des bois relativement purs prélevés dans un territoire de la population du nord du parc national de Wood Buffalo en 1963 et 1965 . L'hypothèse qui est proposée, d'une circulation des gènes restreinte, prédit que : 1) l'introduction du bison des plaines n'a pas submergé tout le patrimoine héréditaire du bison des bois; 2) le mouvement et l'échange génétique entre les dèmes sont limités; et 3 ) les dèmes de bisons des bois pratiquement purs restent intacts longtemps après que l'hybridation a eu lieu. La probabilité de trouver le bison des bois est plus grande dans la région la plus éloignée et inaccessible de Hook Lake des basses terres de Slave River, où un petit groupe survit après une longue chute de la population. Ces animaux pourraient venir - du moins en partie - d'une ancienne population déjà établie avant la création du parc. Des preuves historiques, comportementalistes, morphométriques, photographiques ainsi que des preuves obtenues lors d'observations viennent corroborer cette hypothèse, mais des preuves formelles fournies par les tests taxonomiques disponibles, n'ont pas encore été rassemblées.

La politique actuelle, ainsi que la législation et le droit international accordent au gouvernement les pleins pouvoirs pour protéger et gérer l'espece «menacée» du bison des bois, mais n'accordent aucune protection aux hybrides. Ȧ cause de son statut bio-politique actuel, le troupeau de Hook Lake court le risque imminent de disparaître, à cause de la surexploitation, de la maladie et du trop grand nombre de prédateurs, ou encore à cause de la dépopulation intentionnelle pour faire disparaître la maladie. Si le troupeau de bisons de Hook Lake est constitué de bisons des bois, son changement de statut comporte les implications suivantes: 1) l'accord des pleins pouvoirs au gouvernement pour protéger et gérer ce qui reste du troupeau; 2) l'option de sauver et de restaurer la diversité génétique de la population mondiale du bison des bois; 3) des solutions de rechange qui faciliteraient de beaucoup les stratégies futures de gestion des populations nordiques de bisons vivant en liberté; et 4) une contribution à l'objectif international de retirer le bison des bois de la liste des espèces en voie de disparition.

Mots clés: faune, bison, taxonomie, conservation

Traduit pour le journal par Nésida Loyer.

\section{THE UNIVERSAL WBNP HYBRIDIZATION HYPOTHESIS}

All bison in Wood Buffalo National Park (WBNP) and in the Hook Lake area of the Slave River lowlands (SRL) (Fig. 1) are classified as plains bison (Bison bison bison Linnaeus) $x$ wood bison (B.b. athabascae Rhoads) hybrids. Their classification rests entirely on three assumptions: 1 ) in the years immediately following their introduction, plains bison greatly outnumbered wood bison and swamped the indigenous gene pool; 2) the two subspecies mixed freely throughout their range; and 3) the two subspecies interbred freely. It has also been assumed that the Hook Lake population originated by way of emigration of hybrids from WBNP.

These assumptions are not consistent with evidence that a relatively pure sample of wood bison was collected from the park 35 years after the hybridization episode. This sample was not isolated from other herds of bison occupying the historical northern bison ranges of WBNP. Bison were known to occupy ranges east of the Slave River in historic times and have been reported in the Hook Lake area as early as 1936. The Hook Lake animals form a relatively distinct subpopulation and may be at least partially descended from a unique relict population of wood bison that predates the hybridization episode and the creation of WBNP.

\section{The Hybridization Episode}

Over the protest of some conservation biologists, the Government of Canada implemented a transplant program that has been called "one of the most tragic examples of

\footnotetext{
${ }^{1}$ Arctic College, Box 600 , Fort Smith, Northwest Territories, Canada X0E OP0

(C) The Arctic Institute of North America
} 


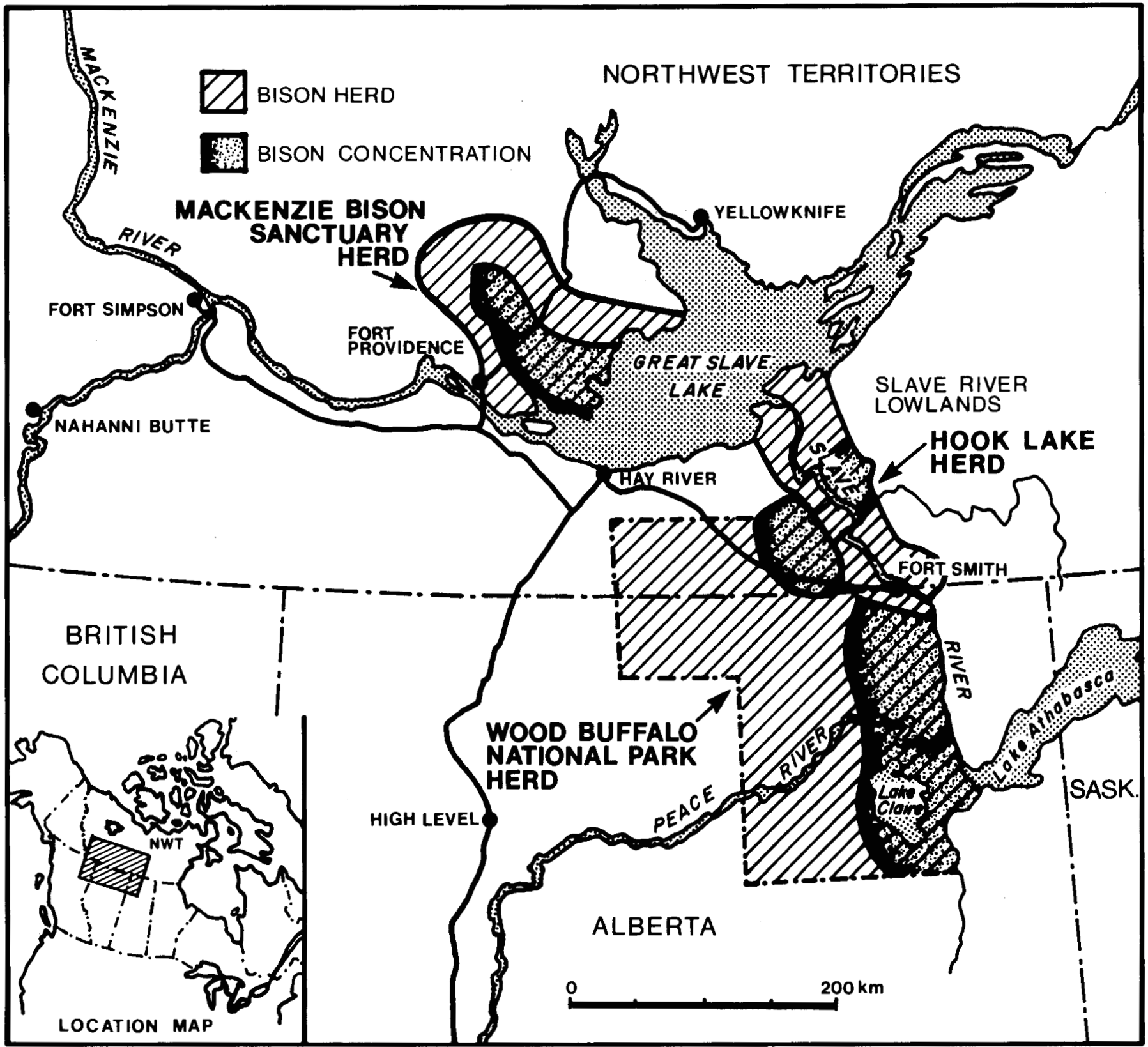

FIG. 1. Location of the major free-ranging populations of wild bison in northern Canada (after Reynolds and Hawley, 1987).

bureaucratic stupidity in all history. . "' (Shepstone, 1932, in Roe, 1970:839). Between 1925 and 1928, 6673 plains bison were transferred from Buffalo National Park at Wainwright, Alberta, and released among an increasing population of indigenous wood bison in WBNP. The introduced animals comprised " 4826 yearlings, 1515 two year olds and 332 three year olds. In all consignments females were in the majority. There were some early setbacks but in the end the young stock thrived. . .' (Soper, 1941:375). Raup (1933) and Soper (1941) believed that the two subspecies mixed and interbred freely in the open prairie habitats west of the Slave River, in the Peace-Athabasca delta and throughout the secondary ranges of the park. Soper estimated a total population of 12000 as early as 1934 .

\section{The "Setbacks" versus the "Swamping" Assumption}

The early setbacks were elaborated by Oldham in his 1946 park superintendents' report. According to Oldham, "no accurate information is available as to the number of animals that succumbed shortly after arrival due to injuries sustained en route as well as those that died due to change of site" (Oldham, 1946:1). His informant, M.J. Dempsey, chief park warden and a long-time resident of the park, estimated only 4000 of the plains bison arrived in the park in fit condition to survive their first winter. The young animals were contaminated with highly contagious diseases. They were shipped on crowded barges for $1120 \mathrm{~km}$ and released into unfamiliar habitat, with no traditions, no leaders and no experience with 
predators. Many of the young animals must have perished. "According to local information, a few years after the Wainwright buffalo were moved into the park many dead animals were found which were neither killed by wolves nor shot. ..' (Oldham, 1946:10). An unknown number of bison wandered up the Peace River and out of the park.

The largest single group of transplants moved into unoccupied habitat south of the Peace River, causing authorities to expand the boundaries of WBNP to include the PeaceAthabasca delta. Many more must have moved long distances from the release site, as was the case with plains bison released in northern Manitoba and wood bison released in Jasper National Park and in the Nahanni (Reynolds, 1982).

Among the surviving animals there would have been very little reproduction for several years. Most of the released animals were female and nearly all were sexually immature. Bison females rarely give birth before they are three years old (Fuller, 1962). Fecundity would be further depressed by the stresses of disease, transfer and acclimatization. The small number of plains bison bulls among the survivors would have contributed very little to reproduction for several years. Plains bison bulls rarely participate in reproduction until they reach social maturity at the age of 5-8 years (McHugh, 1958; Lott, 1974).

Van Zyll de Jong (1986) raised the question of the relative contribution of the two subspecies to the hybrid gene pool. However, the imprecise, ambiguous and often contradictory mixture of speculation and anecdote left by the early authors yields very few safe conclusions. At one extreme we have Soper's estimate of no more than 1 or 2 purebred wood bison per 100 in the southern population and no more than $10-15 \%$ of the entire park population as early as 1934. At the opposite extreme, even if all the plains bison perished or dispersed, the 1500-2000 original wood bison estimated in 1922 increasing at the rate of $7 \%$ per year could have accounted for all the 8000-10 000 bison estimated from the aerial surveys of the park flown in the mid-and late 1940s (Oldham, 1946; Fuller, 1950).

The central point regarding the historical status, distribution and trend of bison in the WBNP region is that historical data are only as reliable as the techniques of the day. Prior to 1946, all population estimates and descriptions of movements, distribution, recruitment and hybridization were based on foot patrols, horse patrols, dog sled surveys and word of mouth. Any modern estimate employing such techniques would be regarded as a wild guess, with no index of accuracy or precision.

In 1946 the airplane was added to the tools available to the early naturalists. However, Carbyn et al. (1987) analyzed the aerial strip census techniques used to estimate bison numbers in WBNP between 1946 and 1970. Their analysis showed technical inconsistencies and imprecision of such magnitude that it was impossible to reconstruct any statistically valid population trend before 1970 . Depending on whom we believe and which assumptions we make, it is possible to reconstruct wildly different conclusions. Few of the quantitative conclusions drawn from data collected prior to 1970 have any statistical validity.

In my opinion, only qualitative conclusions can be drawn with respect to bison population size, status, distribution and trend in the WBNP region prior to 1970 . These include: 1) an unknown number of wood bison survived when WBNP was created in $1922 ; 2$ ) the distribution of these animals included at least two subpopulations; 3) 6673 young plains bison were shipped from Wainwright Buffalo Park; 4) an unknown number perished en route; 5) an unknown number were released among an unknown number of indigenous wood bison; 6 ) the Wainwright bison came from a herd that was contaminated with brucellosis (Brucella abortus) and tuberculosis (Mycobacterium bovis); 7) an unknown number of plains bison perished or dispersed shortly after they were released; 8 ) within a few years many of the plains bison moved south of the Peace River to unoccupied ranges in the PeaceAthabasca delta; 9) some of the wood bison and plains bison hybridized; and 10) some did not.

Based on the early data, Fuller (1957) concluded that:

The original preponderance of plains animals has resulted in the virtual disappearance of the wood buffalo in the pure state. ... There are however in the inaccessible northwest corner of the park, small herds of bison which may be pure or nearly pure athabascae. No natural travel lanes link this area with the remainder of the park which has been taken over by hybrids. [Fuller, 1957:7.]

This is the foundation of the current classification of all bison in WBNP and Slave River lowlands. New evidence and theories yield an alternative hypothesis.

\section{THE LIMITED GENE FLOW HYPOTHESIS}

There is ample evidence of contact between the northern and southern demes in WBNP (Soper, 1941; van Zyll de Jong, 1986; Carbyn et al., 1987), but movement does not equal dispersal and dispersal does not equal gene flow.

... Movement into a new area does not necessarily result in the establishment of immigrant genes . . . aliens if they mate at all are much less likely to reproduce successfully than natives for many reasons including social ostracism, unfamiliarity with new habitat, slightly different microhabitat and microclimatic tolerances . . . and aliens may be genetically incompatible with residents. . . . [Endler, 1977:24.]

In the presence of selective pressure, heterosis may decrease the fitness of hybrid offspring resulting in either a steep or discontinuous cline or eventual elimination of the alien genes. However, if heterosis has a positive or neutral effect on fitness, the hybrid zone will expand and eventually all subpopulations will become genetically undifferentiated (Slatkin, 1973; Endler, 1977). If there are barriers that restrict but do not totally prohibit gene flow, a steep or discontinuous cline may form and persist for many generations. Such a cline is likely to be unstable and will eventually resolve in one of three ways: an undifferentiated zone of hybrids; a discontinuous cline; or elimination of the hybrid zone by negative selection of unfit alien genes.

"If species with large dispersal distances do show strongly differentiated local races, strong selection seems to be operating" (Endler, 1977:26). Some selective pressure must have allowed plains bison and wood bison to differentiate and stay differentiated in spite of the long zone of contact between their historical distributions (van Zyll de Jong, 1986). If the native homozygous wood bison have some selective advantage, then perhaps they are gradually eliminating the 
less fit alien genes from the hybrid zone artificially created over 60 years ago. Even if heterosis is neutral, if genetic exchange between northern and southern demes is blocked or occurs only at low frequency, then rather than universal hybridization, one might find a persistent stepped cline of phenotypic frequencies.

The Task Force on Bison Diseases (1988:2.8) acknowledged that ". . . some researchers maintain that there are still two morphologically different types of bison in the area. It is believed that bison in the northern part of the park and in the SRL more closely resemble wood bison while those in the south are morphologically similar to plains bison."' Van Zyll de Jong (1986:56) hypothesized, "If movement between demes was limited, the Hay Camp and Lake Claire herds would be expected to show the greatest similarity to the AP stock." (A-P refers to the Allard-Pablo herd of plains bison, which supplied the original stock for the Wainwright population.)

There is evidence of geographic barriers in the form of inhospitable habitat between northern and southern WBNP subpopulations and with the Slave River between the northern WBNP subpopulation and the Hook Lake subpopulation (Calef and Van Camp, 1987). Divergent reproductive behaviour can result in assortative mating, another type of barrier to genetic exchange (Endler, 1977; Geist, 1981). Plains bison typically breed in large groups during a rut that is short, synchronous and intense (Lott, 1974). Wood bison breed in small groups during a prolonged, asynchronous, low-intensity breeding season (Calef and Van Camp, 1987; GNWT, 1988; Gates, pers. comm. 1988).

Since nearest neighbours are usually closest relatives (Endler, 1977; Roughgarden, 1979), the lowest frequency of plains bison characteristics would be expected in the ranges most remote from Hay Camp and the Peace-Athabasca delta. The Needle Lake area in the northwest and the Hook Lake area in the northeast are the most remote and inaccessible of the historic bison ranges. Movement from the PeaceAthabasca delta to Hook Lake requires a trip of over 200 $\mathrm{km}$ and the crossing of two major rivers.

These hypotheses predict a low rate of genetic diffusion and a long-term but unstable cline in phenotypic frequencies between the northern and southern subpopulations in WBNP. They predict an even lower rate of exchange between the Hook Lake herds and the epicentres of hybridization in WBNP. The historical evidence of distinct northern and southern subpopulations, the empirical evidence of a small admixture of hybrid genes and the presence of both brucellosis and tuberculosis among the Nyarling River bison (van Zyll de Jong, 1986; Tessaro, 1987; Task Force on Bison Diseases, 1988) are not inconsistent with these hypotheses.

\section{Distinct Northern and Southern Subpopulations}

Prior to the release of the Wainwright bison, all the investigators in the region agreed that there were two distinct subpopulations of wood bison in the area originally designated as WBNP (see Hewitt, 1921; Graham and Siebert, 1923; Seton, 1929; Roe, 1970). The two ranges are separated by an escarpment and strip of jack-pine-dominated habitat 32-48 $\mathrm{km}$ wide (McCallum, 1914, in Roe, 1970). Graham and Siebert (1923) very accurately described the Needle Lake-Nyarling
River complex as an interesting component of the northern range. Fuller's $(1957,1962)$ map showing the distribution of the Hay Camp herd corresponds with the distribution of the southern herd mapped by Graham and Siebert (1923). Even the recent analyses of Carbyn et al. (1987) and the Task Force on Bison Diseases (1988) did not detect significant patterns of movement between the Hay Camp herd and the herds northwest of the Little Buffalo River or east of the Slave (Fig. 2).

Independent analyses of seasonal distribution and movements of free-roaming bison populations in Yellowstone National Park (Meagher, 1973), WBNP (Task Force on Bison Diseases, 1988), the SRL (Calef and Van Camp, 1987) and the MBS (Larter, 1988; Gates, pers. comm. 1988) agree that bison establish home ranges and traditional movement patterns that are highly predictable, except for occasional dispersal episodes and random long-range movements of aging bulls.

\section{Available Diagnostic Criteria}

The differences between the two subspecies are subtle and are complicated by seasonal and individual variation, but they are clearly perceptible to the experienced observer. Few investigators have had the opportunity to observe and compare both subspecies in the field. Geist and Karsten (1977) and Reynolds et al. (1982) provided a series of drawings depicting the differences apparent to the artist's eye (Fig. 3). Peden and Kraay (1979) attempted to distinguish the two subspecies by analyzing a variety of blood characteristics but were unable to separate the subspecies or their hybrids. In spite of the cautions of Shackelton et al. (1975) with respect to the variability and plasticity of some cranial features, van Zyll de Jong's (1986) multivariate craniometric analyses have provided the most rigorous taxonomic tests. He also provided a set of more subjective criteria that is useful in photographic analysis as well as in the field.

The most useful field marks of the wood bison are the angular blockish hump that peaks well in front of the shoulder; the procumbent forelock; the thinner, shorter facial display hair; the long-necked lanky appearance resulting from shorter beard and neck hairs; and the indistinct gradation of the cape hairs to the hind quarters. Less reliable indicators are the thinner, shorter hairs of the penis tuft; the longer, more fully haired tail; and the thinner, less pronounced "chaps" on the forelegs.

The Government of the Northwest Territories (GNWT, 1988) has reported some success in separating the subspecies using electrophoresis of DNA fractions. Recent advances in the technique of DNA "fingerprinting"' are so sensitive they can distinguish individuals and trace breed lines (Jeffreys et al., 1985; Ellesworth et al., 1988; Hoelzel and Amos, 1988), but the resolution of these molecular techniques may be too great for work at the level of species or subspecies.

\section{Relatively Pure Wood Bison in the Northern Herd of WBNP}

As predicted by Soper (1941) and Fuller (1957, 1962), a small, "isolated" group of bison was "discovered" in the upper Nyarling River drainage in northern WBNP. In 1959, a winter road was pushed into the Needle Lake area in prepa- 


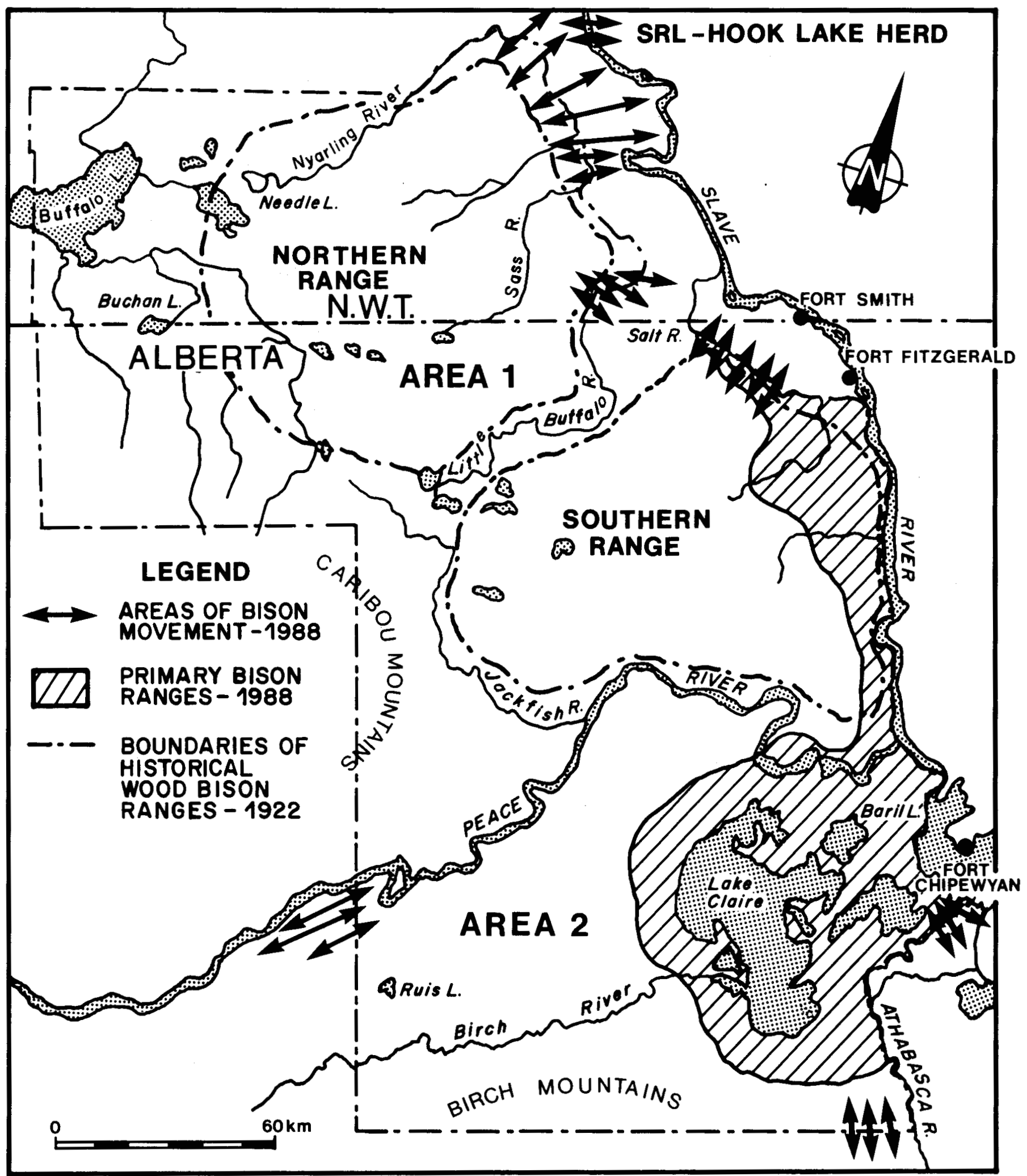

FIG. 2. Locations of transboundary movements of bison in Wood Buffalo National Park compared to the historical northern and southern wood bison ranges (after Graham and Siebert, 1923; Task Force on Bison Diseases, 1988).

ration for the construction of a highway from Fort Smith to Hay River. For the first time the northern range became accessible by road. Five animals were killed and measured and three specimens were compared with a small museum collection of pre-1925 wood bison (Novakowski, 1959). The measurements overlapped and the Nyarling River bison were 


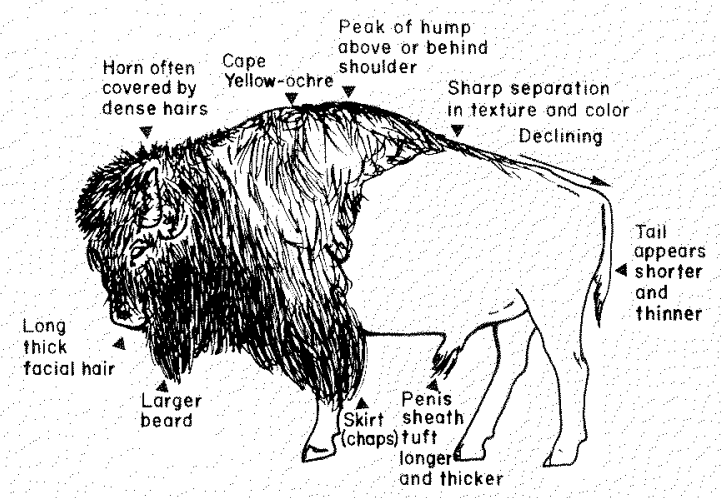

PLAINS BISON BULL

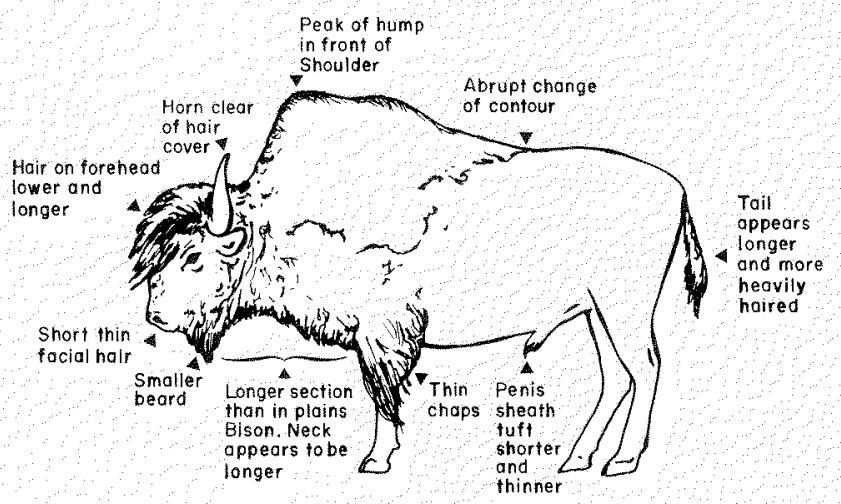

WOOD BISON BULL

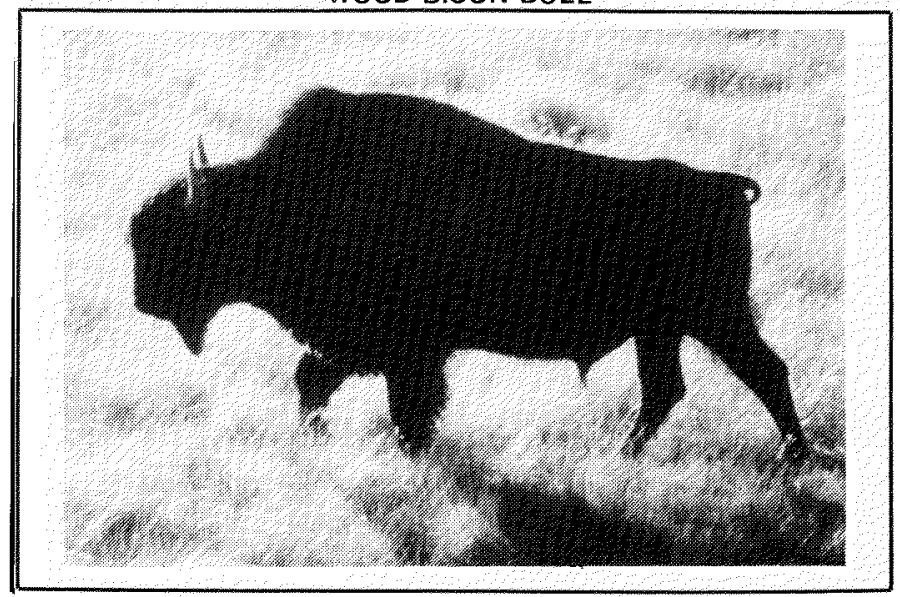

FIG. 3. A comparison of the diagnostic features of plains bison and wood bison bulls with a photograph of a bull taken near Hook Lake. (Drawings after Geist and Karsten, 1977; Reynolds et al., 1982; van Zyll de Jong, 1986; photo by Van Camp, 1978.)

classified as pure wood bison (Banfield and Novakowski, 1960). In 1963 and 1965 small herds were rounded up in the Needle Lake area, then driven to corrals near Fort Smith. They were held for disease testing and the negative reactors were transferred to the Mackenzie Bison Sanctuary (MBS) (18 animals in 1963 minus at least 2 mortalities) and Elk Island National Park (EINP) (23 animals in 1965 plus 3 in 1966) (Novakowski, 1963; Task Force on Bison Diseases, 1988).

Thus, 42 survivors from a single location were the founders of all present wood bison herds (Reynolds, 1980, 1982). They are recognized as an endangered subspecies in the IUCN Red Data Book; included in Appendix 1 of the Convention on
International Trade in Endangered Species (CITES); listed as an endangered subspecies in the N.W.T. Act; and classified as threatened by the Committee on the Status of Endangered Wildlife in Canada (COSEWIC).

Van Zyll de Jong's (1986) multivariate morphometric analyses of the Nyarling River bison and their descendants provided the first statistical confirmation that these animals are distinguishable from plains bison and that they closely resemble the pre-1925 wood bison. There were, however, differences in the expression of some morphologic characters, which "suggests a possible admixture of AP genes of approximately 5\%" (van Zyll de Jong, 1986:56).

Banfield and Novakowski (1960) suggested that the reason for the purity of Nyarling River animals may have been their isolation from the main herds of WBNP hybrids due to "inhospitable and unproductive terrain," and Fuller (1957) claimed there were no natural travel lanes to the remote northwestern extremity of the park. However, Fuller's 1949 aerial survey and an aerial survey entitled "Winter Distribution of Bison - 1957' found in the files of WBNP showed small groups of bison scattered throughout the northern third of WBNP. No bison were located more than $10-16 \mathrm{~km}$ from their nearest neighbours (Carbyn et al., 1987). These could have been the descendants of the northern population.

The Nyarling bison may have been geographically and behaviourally removed from the main concentrations of hybrids in the Hay Camp area and Peace-Athabasca delta, but there is no evidence supporting the hypothesis of isolation from other bands of northern bison. On the contrary, the Nyarling, Klewi and Sass rivers provide excellent natural travel lanes connecting large prairie complexes centred on the Grand Detour area between the Little Buffalo and Slave rivers. If the Nyarling bison were not an isolated anomaly, then perhaps they were representative of a larger northern subpopulation of relatively intact wood bison. Unfortunately, during the winter of 1964-65, 522 bison were slaughtered in a vain effort to prevent the spread of anthrax (Bacillus anthracis) by depopulating the Grand Detour area (Novakowski, 1965; Choquette and Broughton, 1967). The Grand Detour population survives but has never recovered (Van Camp and Calef, 1987).

\section{THE HOOK LAKE HERD}

The earliest record of bison in the Slave River lowlands was provided by Hearne (1971) in 1795. With Matonabee, he hunted bison during January 1772 in the area south of Great Slave Lake and east of the Slave River. The wood bison was believed to have been extirpated from nearly all of its historical range between 1850 and 1880 ; however, relict populations of wood bison were reported in the upper Hay River and in the Liard valley until at least 1897 (Jarvis, 1897, in Soper, 1941).

Curiously, one of the maps published by Graham and Siebert (1923) shows a "Resolution Bison Range" east of the Slave River between Fort Smith and Great Slave Lake. Soper (1941) noted a group of bison east of the Slave River near "La Grande Detour," but he did not believe them to be resident. Art Look (pers. comm. 1988) hunted and trapped along the lower Taltson River as a young man. He can recall bison in the Hook Lake area as early as 1936. 
The Hook Lake population was believed to have originated from animals dispersing from WBNP during the 1940s. Fuller (1950) originally believed that the animals wintering east of the Slave returned to summer ranges in the park. The universal hybridization hypothesis predicted that all bison in WBNP were hybrids (with the possible exception of the small herds in the northwest). Therefore, it followed that the Hook Lake herd were also hybrids. In the absence of arguments to the contrary, these animals continue to be classified and managed as if they are hybrids (see Fuller, 1962; Reynolds and Hawley, 1987).

Fuller (1950), on the first aerial census outside the boundaries of WBNP, estimated 200 bison between the Slave and Taltson rivers during the winter of 1948-49. Van Camp and Calef (1987) reviewed the irruption and collapse of the Hook Lake population between 1949 and 1983. In the early 1970 s the herd was estimated to number nearly 2000 , but in March 1987 only 183 survivors could be found (Gates, pers. comm. 1988) (Fig. 4).

The limited gene flow hypothesis predicts that if bison from the northern range of WBNP dispersed across the Little Buffalo and Slave rivers early in the 1940s, then the immigrant

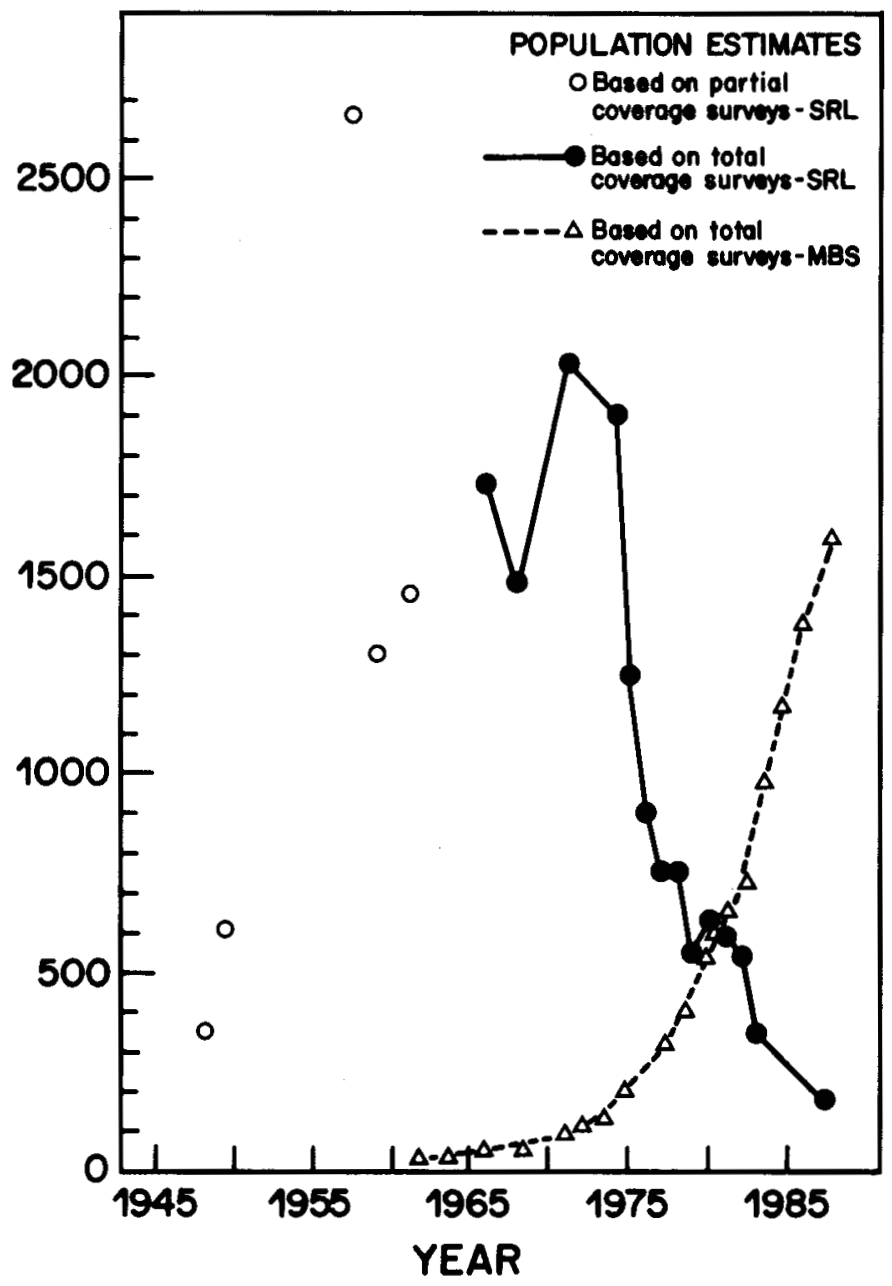

FIG. 4. A comparison of the population irruption of wood bison in the Mackenzie Bison Sanctuary with the population collapse of the bison of the Hook Lake area, N.W.T. (after Reynolds and Hawley, 1987; GNWT, 1987). animals could very likely have been relatively pure wood bison. They would have been exposed to the possibility of hybridization for less than 15 years, fully 20 years less than the relatively pure animals collected from the Nyarling River in the early $1960 \mathrm{~s}$.

The ranges east of the Slave are not visible from the river and could have easily been overlooked by river travelers. In the early days of WBNP the attention of all investigators was drawn to the ranges within the boundaries of WBNP, which were visible and easily accessible from the main river routes. Graham and Siebert (1923) showed bison ranges east of the Slave River and Art Look's 1936 report places bison along the Taltson River within a decade of the plains bison releases in WBNP. Soper (1941) noted bison east of the Slave River and Calef and Van Camp (1987) could not detect movement of bison between the Hook Lake herd east of the Slave River and the Grand Detour herds ranging in and out of WBNP west of the Slave. The possibility that the Hook Lake bison are at least partially descended from a unique relict population cannot be overlooked.

I spent two years in the Hook Lake area studying the predator-prey relationship between wolves and bison (Van Camp and Calef, 1980; Calef and Van Camp, 1987; Van Camp and Calef, 1987; Van Camp, 1987). Although bison taxonomy was not the focus of attention, I repeatedly noticed the similarity between the Hook Lake bison and those I had observed among the wood bison herd in EINP. When I examined my photographs of Hook Lake bulls according to van Zyll de Jong's (1986) weighted character index, I could not separate the Hook Lake bulls from wood bison bulls. (See Figure 3 for a comparison of plains bison, wood bison and Hook Lake bison bulls.)

If a relatively pure herd of wood bison invaded the Hook Lake area in the early 1940s, it is likely that they have remained relatively pure, perhaps even more pure than those transplanted to the MBS and EINP. If the Hook Lake bison are in fact descendants of a relict population, then they form a uniquely conserved gene pool that may contain diversity not represented among the descendants of the Nyarling River bison. Rather than a low-value population of hybrids, the Hook Lake survivors may be a highly valuable population of pure wood bison. Yet, in the assessment of the Task Force on Bison Diseases (1988:348), "the Hook Lake herd is a group of diseased hybrids which appears to be nearing extirpation."

\section{Current Management Consequences}

Without an objective empirical test, the subspecific classification is more a bio-political than a biological designation. Quibbling about subspecific taxonomy may seem trivial; however, the interpretation and subsequent management implications are profound. The N.W.T. Act recognizes wood bison as an endangered subspecies and empowers the GNWT to protect and manage them, including the authority to regulate harvest and use by aboriginal hunters. The GNWT is powerless to regulate aboriginal use of hybrid bison. The result of this bio-political taxonomy has been the growth and proliferation of the transplanted MBS and EINP herds and the concurrent demise and near extirpation of the Hook Lake population (see Figure 4). 
The Task Force on Bison Diseases (1988) has identified a set of nine alternatives for dealing with brucellosis and tuberculosis in the northern bison. Among the most feasible alternatives is "Salvage of wood bison stock from WBNP and/or addition of wood bison from Elk Island National Park and the Mackenzie Bison Sanctuary to form the nucleus of a disease free breeding herd that will ultimately replace the diseased hybrid herd in the park and the Slave River Lowlands" (Executive Summary:x).

The Hook Lake population of bison is likely to be extirpated in the next decade if it remains classified as hybrid. The world may lose this potentially unique source of biological diversity simply because of an incorrect taxonomic designation.

\section{THE MANAGEMENT IMPLICATIONS OF A STATUS CHANGE}

If objective taxonomic tests find that the Hook Lake animals cannot be distinguished from the pre- 1925 wood bison or from the descendants of the Nyarling wood bison, then the Hook Lake population must be reclassified as endangered wood bison. Such a reclassification would have far-ranging implications:

1) The GNWT would become accountable for the management of the Hook Lake bison as an endangered subspecies and would be empowered to regulate aboriginal harvesting. Overharvesting by aboriginal, general hunting licence (GHL) hunters and overpredation by wolves have been among the major causes contributing to the decline of this population. The failure of GHL hunters to cooperate by voluntarily reducing their hunting caused the GNWT to discontinue active management of this resource in 1979 (Heard, 1983; Van Camp, 1987).

2) Any effort to eradicate diseases in the bison of the WBNP region would have to recognize the unique status of the Hook Lake animals as an endangered subspecies. Special efforts would be required to salvage their contribution to the genetic diversity of wood bison. These might include selective capture-test-slaughter programs to isolate a representative disease-free cadre that could be united with other wood bison to form founder populations for reintroduction to depopulated ranges.

3) Recognition of a single subspecies on all northern ranges would greatly simplify future management options. No precautions would be necessary to prevent mixing of subpopulations. On the contrary, managers would be free to encourage linking of large subpopulations across broad expanses of range, perhaps the most appropriate strategy for reducing the probability of extinction (Diamond, 1975, 1984; Soulé, 1986, 1987; Van Vuren, 1987).

4) All modern herds recognized as wood bison are descended from two isolated populations that have passed through genetic bottlenecks of only 16 (MBS) and 26 (EINP) individuals. The reproductive performance of European bison (Bison bonasus) decreased as founder populations became increasingly inbred (Olech, 1987). The genetic diversity of modern wood bison herds could be enhanced with the addition of another source of breeding stock. New sources of diversity may play an important role in maintaining the vigour of new founder populations if an eradication and replacement program becomes necessary.
5) International species conservation strategies should be based on real biological entities rather than human decisions on subspecific taxonomy. They should recognize the value of unique and relict populations, even those contaminated by hybridization or disease, to the overall objective of conserving the genetic diversity of endangered species (W. Frey, pers. comm. 1988). The international objective of removing wood bison from danger of extinction would be served by the recognition of other free-ranging herds of wood bison.

\section{CONCLUSION}

The current classification of the Hook Lake herd as hybrids is not supported by the available evidence. Empirical tests of subspecific bison taxonomy have not been applied. Yet, the fate of this potentially unique resource is tied directly to its current taxonomic status. Available tests should be applied to the Hook Lake animals to reassess their status before all future management options are precluded by extirpation.

\section{ACKNOWLEDGEMENTS}

I wish to acknowledge the assistance of David King Beaulieu and those like him who truly care about the bison.

\section{REFERENCES}

BANFIELD, A.W.F., and NOVAKOWSKI N.S. 1960. The survival of the wood bison (Bison bison athabascae Rhoads) in the Northwest Territories. National Museum of Canada, Natural History Papers 8:1-6.

CALEF, G.W., and VAN CAMP, J.D. 1987. Seasonal distribution, group size and structure and movements of the bison herds. In: Reynolds, H.W., and Hawley, A.W.L., eds. Bison ecology in relation to agricultural development in the Slave River Lowlands, N.W.T. Canadian Wildlife Service Occasional Paper No. 63:15-20.

CARBYN, L.N., ANIONS, D., and HUISMAN, D. 1987. A review of the status of bison in Wood Buffalo National Park. Unpubl. report. Available at Canadian Wildlife Service, 4999 - 98 Avenue, Edmonton, Alberta T6B $2 \times 3$.

CHOQUETTE, L.P.E., and BROUGHTON, E. 1967. Anthrax in bison, Wood Buffalo National Park and the Northwest Territories. Unpubl. Progress Report No. CWSC 1109. Available at Canadian Wildlife Service, Environment Canada, Ottawa, Ontario K1A 0E7. 23 p., Addendum A (1 p.) and Addendum B (25 p.).

DIAMOND, J.M. 1975. The island dilemma: lessons of modern biogeographic studies for the design of natural reserves. Biological Conservation 7:129-146. . 1984. Historic extinctions: a Rosetta Stone for understanding prehistoric extinctions. In: Martin, P.S., and Klein, R.G., eds. Quaternary Extinctions: a prehistoric revolution. Theson: University of Arizona Press. 824-862.

ELLSWORTH, D.L., ROSEBERRY, J.L., and KLIMSTRA, W.D. 1988. Biochemical genetics of wild, semi-wild and game farm northern bobwhites. Journal of Wildlife Management 52(1):138-144.

ENDLER, J.A. 1977. Geographic Variation, Speciation, and Clines. Princeton: Princeton University Press. 246 p.

FULLER, W.A. 1950. Aerial census of bison in Wood Buffalo National Park and vicinity. Journal of Wildlife Management 14:445-451. 1957. The biology and management of the bison of Wood Buffalo National Park. Ph.D. dissertation, University of Wisconsin. 130 p. 1962. The biology and management of the bison of Wood Buffalo National Park. Canadian Wildlife Service Wildlife Management Bulletin Series 1, No. 16. 52 p. (Reprinted 1966.)

GEIST, V. 1981. Behavioural adaptive strategies in mule deer. In: Walmo, O.C., ed. Mule and Black-tailed Deer of North America. Lincoln: University of Nebraska Press. 157-223. 
and KARSTEN, P. 1977. The wood bison (Bison bison athabascae Rhoads) in relation to hypotheses on the origin of the American bison (Bison bison bison Linnaeus). Zeitschrift fur Saügetierkunde 42(2):119-127. GOVERNMENT OF THE NORTHWEST TERRITORIES. 1987. Mackenzie Wood Bison management plan. Yellowknife: Department of Renewable Resources, Government of the Northwest Territories. $20 \mathrm{p}$. 1988. 1987/88 Annual report: bison ecology program summary of activities. Unpubl. progress report. Available at Department of Renewable Resources, P.O. Box 390, Fort Smith, N.W.T. X0E 0P0. 14 p.

GRAHAM, M., and SIEBERT, F.V. 1923. Canada's wild buffalo: observations in Wood Buffalo National Park. Ottawa: Department of Interior. $17 \mathrm{p}$.

HEARD, D.C. 1983. Historical and present status of wolves in the Northwest Territories. In: Carbyn, L.N., ed. Wolves in Canada and Alaska. Canadian Wildlife Service Report Series No. 45:44-47.

HEARNE, S. 1971. A Journey from Prince of Wales Fort in Hudson Bay to the Northern Ocean. Edmonton: M.G. Hurtig Ltd. 458 p.

HEWITT, C.G. 1921. The Conservation of the Wildlife of Canada. New York: Scribners. $344 \mathrm{p}$

HOELZEL, A.R., and AMOS, W. 1988. DNA fingerprinting and "scientific" whaling. Nature 333:305.

JEFFREYS, A.J., WILSON, V., and THEIN, S.L. 1985. Hypervariable "mini-satellite" regions in human DNA. Nature 314:67-73.

LARTER, N.C. 1988. Home range size and movement patterns of male and female wood bison in the Mackenzie Bison Sanctuary, Northwest Territories, Canada. Journal of Northern Sciences 2:41-48.

LOTT, D.F. 1974. Sexual and aggressive behavior in adult male American bison (Bison bison). In: Geist, V., and Walther, F., eds. The behavior of ungulates and its relation to management. IUCN Publication New Series 24(1):382-394.

McHUGH, T. 1958. Social behavior of the American Buffalo (Bison bison bison). Zoologica 43(1):1-40.

MEAGHER, M.M. 1973. The bison of Yellowstone National Park. U.S. National Park Service Scientific Monograph Series No. 1. 161 p.

NOVAKOWSKI, N.S. 1959. Report on the investigation of probable wood bison in the Nyarling River area and an investigation of historical wood bison range in the Fort Providence area. Canadian Wildlife Service unpubl. report. Available at Canadian Wildlife Service, 4999 - 98 Avenue Edmonton, Alberta T6B 2X3. 13 p. and appendix.

1963. Wood bison transfer completion report. Canadian Wildlife Service unpubl. report CWS-35-63. Available at Canadian Wildlife Service, 4999 - 98 Avenue, Edmonton, Alberta T6B 2X3. 4 p.

1965. Slaughter report - Grande Detour 1964-65. Canadian Wildlife Service unpubl. report CWSC 1105 . Available at Canadian Wildlife Service, Environment Canada, Ottawa, Ontario K1A 0E7. 4 p. and 2 appendices.

OLDHAM, E.G. 1946. Buffalo count Wood Buffalo National Park. Superintendents Report, Wood Buffalo National Park, Fort Smith, N.W.T. XOE OP0. $11 \mathrm{p}$.

OLECH, W. 1987. Analysis of inbreeding in European bison. Acta Theriologica 32:373-386.

PEDEN, D.G., and KRAAY, G.J. 1979. Comparison of blood characteristics in plains bison, wood bison and their hybrids. Canadian Journal of Zoology 57:1778-1784.
RAUP, H.M. 1933. Range conditions in the Wood Buffalo Park of Western Canada with notes on the history of the wood bison. Special Publications of the Amercian Committee for International Wildlife Protection 1(2):1-52.

REYNOLDS, H.W. 1980. Wood bison - past, present and future. Canadian Wildlife Administration 6:75-78.

1982. An endangered species program brings Wood Bison to Nahanni. Zoonooz LV(7):4-8.

and HAWLEY, A.W.L. 1987. Bison ecology in relation to agricultural development in the Slave River Lowlands, N.W.T. Canadian Wildlife Service Occasional Paper 63. 74 p.

, GLAHOLT, R.D., and HAWLEY, A.W.L. 1982. Bison (Bison bison). In: Chapman, J.A., and Feldhamer, G.A., eds. Wild Mammals of North America. Baltimore: Johns Hopkins University Press. 972-1007.

ROE, F.G. 1970. The North American Buffalo: a critical study of the species in its wild state. Toronto: University of Toronto Press. $991 \mathrm{p}$.

ROUGHGARDEN, J. 1979. Population Genetics and Evolutionary Ecology: an introduction. New York: Macmillan Publishers. $634 \mathrm{p}$.

SETON, E.T. 1929. Lives of Game Animals. Garden City, New York: Doubleday, Doran \& Co. Vol. 3, Part 2. 413-780.

SHACKELTON, D.M., HILLS, L.V., and HUTTON, D.A. 1975. Aspects of variation in cranial characters of plains bison (Bison bison bison Linnaeus) from Elk Island National Park. Journal of Mammalogy 56(4):871-877.

SLATKIN, M. 1973. Gene flow and selection in a cline. Genetics 75:733-756.

SOPER, J.D. 1941. History, range and home life of the northern bison. Ecological Monographs 11:349-412.

SOULE, M.E. 1986. Conservation Biology: the science of scarcity and diversity. Sunderland, Mass.: Sinauer. $560 \mathrm{p}$.

1987. Viable Populations for Conservation. Cambridge: Cambridge University Press. 189 p.

TASK FORCE ON BISON DISEASES. 1988. Evaluation of brucellosis and tuberculosis in bison in northern Canada. Report of the task force on bison diseases. Fort Smith: Government of the Northwest Territories, Department of Renewable Resources. 228 p. and appendix.

TESSARO, S.V. 1987. A Descriptive and Epizootiological Study of Brucellosis and Tuberculosis in Bison in Northern Canada. Ph.D. thesis, Western College of Veterinary Science, University of Saskatchewan. $268 \mathrm{p}$.

VAN CAMP, J.D. 1987. Predation on bison. In: Reynolds, H.W., and Hawley, A.W.L., eds. Bison ecology in relation to agricultural development in the Slave River Lowlands, N.W.T. Canadian Wildlife Service Occasional Paper No. 63:25-33.

and CALEF, G.W. 1980. Only the rocks remember. Nature Canada $9(3): 40-53$

1987. Population dynamics of bison. In: Reynolds, H.W., and Hawley, A.W.L., eds. Bison ecology in relation to agricultural development in the Slave River Lowlands, N.W.T. Canadian Wildlife Service Occasional Paper No. 63:21-24.

VAN VUREN, D. 1987. Bison west of the Rocky Mountains: an alternative explanation. Northwest Science 61(2):65-69.

VAN ZYLL DE JONG, C.G. 1986. A systematic study of recent bison with particular consideration of the wood bison (Bison bison athabascae Rhoads 1898). Natural Science No. 6. Ottawa: National Museums of Canada. $69 \mathrm{p}$ 